\title{
Evaluation of different corn textures in dry grain or silage forms for piglets from 7 to $15 \mathrm{~kg}^{1}$
}

\author{
José Vieira Neto², Vinícius de Souza Cantarelli², Elias Tadeu Fialho², Márcio Gilberto \\ Zangeronimo $^{3}$, Nikolas de Oliveira Amaral ${ }^{2}$, Paulo Borges Rodrigues ${ }^{2}$
}

\author{
1 Pesquisa financiada pela FAPEMIG. \\ 2 Departamento de Zootecnia - UFLA. \\ ${ }^{3}$ Departamento de Medicina Veterinária - UFLA.
}

\begin{abstract}
The objective of this study was to evaluate different textures and storage forms of corn in piglet diets. Two experiments were conducted, one of which tested digestibility of nutrients and the other diet performance. In the digestibility trial, 24 crossbred (Landrace $\times$ Large White) barrows with an initial weight of $18.7 \pm 1.5 \mathrm{~kg}$ were used. They were kept in metabolic cages in a randomized block design using the factorial arrangement $2 \times 2$ (type of corn - dent and flint $\times$ type of storage - moist grain silage and dry grain) and six replicates, with one animal as the experimental unit. The values of metabolizable energy (ME) obtained were $3841 \mathrm{kcal}$ of ME/kg of dry matter (DM) from dry corn, $3912 \mathrm{kcal}$ of ME/kg of DM from moist corn, $4022 \mathrm{kcal}$ of DM from ensiled dry corn and $3928 \mathrm{kcal}$ of ME/kg of DM from ensiled humidity corn. The ensilage process increases the digestibility coefficient of dry matter and crude protein and increases the digestible energy of the diets, independent of the process form. The type of corn did not influence these variables. In the performance trial, 60 barrows (initial weight of $6.5 \pm 1.5 \mathrm{~kg}$ ) of the same stock were used during 28 days of post-weaning distributed in the same experimental design, with five replicates and three animals as the experimental unit. The treatments did not influence the daily weigh gain or the daily feed intake. The dentate corn and the ensilage process decreased the feed conversion of the independent form (no significant interaction). The substitution of dry for ensilage corn increased the digestibility of the nutrients in the diets and the feed conversion of the piglets from 7 to $15 \mathrm{~kg}$. Dentate corn promotes best feed conversion in this phase.
\end{abstract}

Key Words: digestibility, ensilage, nursery phase, nutrition, performance, swine

\section{Avaliação dos milhos dentado e duro fornecidos em forma de grãos secos e de silagem de grãos úmidos para leitões dos 7 aos $15 \mathrm{~kg}$}

RESUMO - Objetivou-se com este estudo avaliar os efeitos do tipo de milho (duro e dentado) e da forma de armazenamento (grãos secos ou silagem de grãos úmidos) no valor nutricional das rações e no desempenho de leitões dos 7 aos 15 kg. No ensaio de digestibilidade, utilizaram-se 24 leitões machos castrados (peso inicial de 18,7 \pm 1,5 kg), mestiços Landrace $\times$ Large White, mantidos em gaiolas de metabolismo em delineamento de blocos casualisados em esquema fatorial $2 \times 2$, com seis repetições, considerando um animal por parcela experimental. Os valores de energia metabolizável (EM) obtidos foram: 3.841 kcal de EM/kg de matéria seca (MS) para o milho seco; $3.912 \mathrm{kcal}$ de EM/kg de MS para o milho úmido; $4.022 \mathrm{kcal}$ de EM/kg de MS para o milho ensilado seco; e $3.928 \mathrm{kcal}$ de EM/kg de MS para o milho ensilado úmido. O processo de ensilagem do milho melhorou os coeficientes de digestibilidade da matéria seca e da proteína bruta e a energia digestível das rações, independentemente da forma de armazenamento, ao passo que os tipos de milho não influenciaram essas variáveis. No ensaio de desempenho, foram utilizados 60 leitões (peso inicial de 7,3 \pm 1,2 kg) machos castrados, também mestiços Landrace $\times$ Large White, mantidos durante 28 dias na creche, em mesmo delineamento, porém com cinco repetições e três animais por unidade experimental. O tipo de milho e a forma de armazenamento não influenciaram o ganho de peso e o consumo de ração. O milho dentado e o processo de ensilagem melhoraram a conversão alimentar de forma independente (interação não-significativa). A substituição do milho seco pela silagem de grãos úmidos melhora a digestibilidade dos nutrientes das rações e a conversão alimentar de leitões dos 7 aos 15 kg; além disso, o milho dentado promove melhor conversão alimentar nesse período. 


\section{Introduction}

Corn is one of the most important feeds in the diet of pigs in Brazil, as it represents about $70 \%$ of their diets. However, the types of corn usually marketed in this country have variable chemical compositions and physical properties that directly affect nutritional value. Nutritional value may also be affected by the way corn is stored (Coors et al., 1999).

Corn grains are composed of pericarp, endosperm and embryo. The pericarp is rich in fiber, the endosperm has significant amounts of protein and starch, and the embryo is rich in protein and oil (Watson, 1987). However, the hybrids and varieties of corn in Brazil have different quantities of these nutrients, which varying according to climatic conditions and soil type (Corrêa, 2001).

Moist grain silage is a form of storage used by producers because, in addition to lower costs of production during the season, it can result in a feed of better nutritional value compared to dry corn (Coors et al., 1999). Fornasieri Filho (1992) used the texture of the endosperm to describe corn vitriosity and to classify corn as flint, semi-flint, semi-dent and dent. The classification is determined by protein molecular structure and starch molecular structure, particularly in the pericarp. Depending upon the combination, the starch in the protein may be unavailable or only partially available to young pigs, in which the activities of digestive enzymes are lower (Lima, 2001). However, the process of wet corn silage can reduce this effect and facilitate the activities of digestive enzymes, making the nutrients more available for absorption. Wet corn silage therefore can improve the nutritional value of ensiled grain.

In this study, it was evaluated the nutritional values of diets containing flint and dent corn in the form of dry grain or wet silages for piglets in the initial phase.

\section{Materials and Methods}

Two experiments, one for digestibility of nutrients and the other for performance, were carried out in the Departamento de Zootecnia of Universidade Federal de Lavras (UFLA), Lavras, southern Minas Gerais, in Brazil.

Two corn hybrids (flint and dent) were used in both experiments. They were grown at the same location and under the same climatic and agronomic conditions. After reaching the point of physiological maturity (moisture between 28\% and 32\%), the grains were collected by conventional combine and kept in a clean area. Corn was properly covered with canvas for 24 hours for moisture standardization. Part of the corn was ground in a mill with a 2-mm sieve, and wet cornmeal obtained from each variety was ensiled in 35-kg PVC silos under cylindrical compression for a period of 35 days. The rest of the corn was kept clean with approximately $87 \%$ dry matter and stored in silos at the factory to feed the farm. Before its use in feeding, both varieties of non-corn silage were crushed in the mill with a 2-mm sieve.

In the digestibility assay, it was used 24 Landrace $x$ Large White barrows with an initial weight of $18.7 \pm 1.5 \mathrm{~kg}$, housed individually in cages and with similar metabolisms to those described by Pekas (1968) and adapted according to methodology reported by Sales et al. (2003). They were housed in a room with air conditioning to control the temperature $\left(20.0 \pm 1.5^{\circ} \mathrm{C}\right)$.

The experimental period lasted for 11 days, divided into 7 days of adaptation to the animal cages and experimental diets and 4 days for total collection of feces and urine.

The experimental design was in randomized $2 \times 2$ factorial blocks (type of maize - dent and flint $-\times$ type of storage - moist grain silage and dry grain) with six replicates and one animal per experimental unit. The blocks were formed according to the weights of the animals.

The diets were formulated using corn, soybean meal and modified milk powder and supplemented with vitamins and minerals in accordance with the recommendations of Rostagno et al. (2005) (Tables 1 and 2).

The diets containing corn in the form of dry grain were mixed all at once at the beginning of the experiment, while those with grain moisture silages were mixed daily in the late afternoon. All animals were provided feed based on metabolic weight $\left(\mathrm{BW}^{0,75}\right)$ adjusted by the lower consumption of animal intake during the adjustment period. The amount calculated for each animal was divided into two equivalents and offered at 8 and $16 \mathrm{~h}$. Water was provided ad libitum throughout the experimental period. To determine the beginning and end of collection, ferric oxide $\left(\mathrm{Fe}_{2} \mathrm{O}_{3}\right)$ was used as a fecal marker.

Feces were collected daily, placed in plastic bags and kept in a freezer $\left(-10^{\circ} \mathrm{C}\right)$ prior to analysis. Urine was collected daily in plastic buckets with filtration for retention of dirt and $20 \mathrm{~mL}$ hydrochloric acid ( $\mathrm{HCl} 0.25 \mathrm{~N}$ ) to avoid possible loss of nitrogen resulting from the proliferation of microorganisms. To standardize the volume of urine obtained from all animals, water was added to bring the collection to 2,000 mL/day for each animal. Of this total, an aliquot of $200 \mathrm{~mL}$ was removed, conditioned in bottles and kept in a freezer $\left(-10^{\circ} \mathrm{C}\right)$ prior to analysis. At the end of 
Table 1- Nutritional composition of the ingredients experimental diet ${ }^{1}$

\begin{tabular}{|c|c|c|c|c|c|c|}
\hline Ingredient & $\begin{array}{l}\text { Dry dent } \\
\text { corn }\end{array}$ & $\begin{array}{l}\text { Dry flint } \\
\text { corn }\end{array}$ & $\begin{array}{l}\text { Ensilage dent } \\
\text { corn }\end{array}$ & $\begin{array}{l}\text { Ensilage flint } \\
\text { corn }\end{array}$ & $\begin{array}{c}\text { Soybean } \\
\text { meal }\end{array}$ & $\begin{array}{c}\text { Modified } \\
\text { milk powder }\end{array}$ \\
\hline Dry matter $(\%)^{2}$ & 87.2 & 87.1 & 67.3 & 70.4 & 88.2 & 94.7 \\
\hline Crude protein $(\%)^{2}$ & 9.97 & 10.06 & 9.41 & 8.72 & 51.7 & 17.55 \\
\hline Calcium $^{2}$ & 0.03 & 0.03 & 0.03 & 0.03 & 0.27 & 0.79 \\
\hline Phosphorus $(\%)^{2}$ & 0.27 & 0.27 & 0.28 & 0.27 & 0.2 & 0.72 \\
\hline Lysine (\%) & $0.32^{3}$ & $0.28^{3}$ & - & - & 2.78 & 0.95 \\
\hline
\end{tabular}

${ }_{1}^{1}$ Values expressed in dry matter.

${ }^{2}$ Values from Animal Research Laboratory of UFLA.

${ }^{3}$ Values from Cantarelli (2003).

Table 2 - Composition of experimental diets

\begin{tabular}{|c|c|c|c|c|}
\hline Item & Dry dent corn & Dry flint corn & Ensilage dentate corn & Ensilage flint corn \\
\hline Dry corn & 54.40 & 54.40 & - & - \\
\hline Moist grain silage & - & - & 54.40 & 54.40 \\
\hline Soybean meal & 32.40 & 32.40 & 32.40 & 32.40 \\
\hline Soybean oil & 3.60 & 3.60 & 5.00 & 5.00 \\
\hline Dicalcium phosphate & 1.50 & 1.50 & 1.50 & 1.50 \\
\hline Limestone & 0.57 & 0.57 & 0.57 & 0.57 \\
\hline L-threonine $98,5 \%$ & 0.11 & 0.11 & 0.11 & 0.11 \\
\hline L-lysine $\mathrm{HCl}$ 78\% & 0.35 & 0.35 & 0.35 & 0.35 \\
\hline Vitamin $\operatorname{mix}^{1}$ & 0.10 & 0.10 & 0.10 & 0.10 \\
\hline Mineral $\operatorname{mix}^{2}$ & 0.10 & 0.10 & 0.10 & 0.10 \\
\hline Antibiotic ${ }^{3}$ & 0.10 & 0.10 & 0.10 & 0.10 \\
\hline Antioxidant & 0.10 & 0.10 & 0.10 & 0.10 \\
\hline Digestible energy $(\mathrm{kcal} / \mathrm{kg})^{5}$ & 3912 & 3841 & 3928 & 4022 \\
\hline Digestible lysine $(\%)^{5}$ & 1.440 & 1.440 & 1.440 & 1.440 \\
\hline Digestible methionine $(\%)^{5}$ & 0.745 & 0.745 & 0.745 & 0.745 \\
\hline Digestible threonine $(\%)^{5}$ & 1.145 & 1.145 & 1.145 & 1.145 \\
\hline Digestible triptophan $(\%)^{5}$ & 0.681 & 0.681 & 0.681 & 0.681 \\
\hline
\end{tabular}

${ }^{1}$ Composition/kg of product: vit. A, 8,000,000 UI; vit. D3, 1,200,000 UI; vit. E, 20 g; vit. K3, 2.5 g; vit. B1, 1 g; riboflavin (B2), 4 g; piridoxine (B6), 2 g; vit. B12, 20 cg; niacin, $25 \mathrm{~g}$; pantothenic acid, $10 \mathrm{~g}$; folic acid, $600 \mathrm{mg}$; biotin, $50 \mathrm{mg}$; vit. C, $50 \mathrm{~g}$; antioxidant, $125 \mathrm{mg}$.

${ }^{2}$ Composition/kg of product: selenium, 500 mg; Fe, 70 g; Cu, 20 g; Mn, 40 g; Zn, 80 g; I, 800 mg; Co, 500 mg.

3 Granulated tylosine.

${ }^{4}$ Values from Animal Research Laboratory of UFLA.

${ }^{5}$ Values from Rostagno et al. (2005).

the collection, the feces and urine were homogenized for use in laboratory tests. The other method procedures followed those described by Fialho et al. (1979).

The contents of dry matter, crude protein and energy in the diets, feces and urine were determined in the laboratory according to methodology described by AOAC (1995). It was analyzed the coefficient of digestibility of dry matter, crude protein, digestible energy and gross energy of diets.

In the performance experiment, 60 weaned, castrated male and female piglets with an initial weight of $7.3 \pm 1.2 \mathrm{~kg}$ were used. They were housed in brick rooms in a nursery hall in groups of three, and kept in pens $(2.00 \times 1.20 \mathrm{~m})$ equipped with semi-automatic feeders and drinker-type pacifiers for 28 days. The temperature was controlled with heating lamps and fans. Before housing the animals, the room was properly cleaned, disinfected and maintained fallow for a minimum period of seven days.

The same experimental design was used in this experiment as that in the digestibility experiment; however, there were five replicates and three animals per pen. 
The diets were given ad libitum after weighing. The diets containing moist grain silage were mixed daily in the afternoon and delivered to animals after cleaning the feeders. All orts were weighed to determine actual animal consumption. During the experimental period, water was provided ad libitum.

The animals were weighed at the beginning and at the end of the experimental period to determine feed effects on weight gain.

The average daily gain, average daily feed intake and feed effect on gain were analyzed. All data were submitted to variance analysis using the statistical package SISVAR described by Ferreira (2000).

\section{Results and Discussion}

The minimum and maximum temperatures recorded during the experiment were $24.5 \pm 1.4^{\circ} \mathrm{C}$ and $28.1 \pm 1.8^{\circ} \mathrm{C}$, respectively, and were above the term neutrality zone, which is 20 to $22^{\circ} \mathrm{C}$ (Lima et al., 1999).

There were no interactions $(\mathrm{P}>0.05)$ between corn types and forms of storage for the coefficients of digestibility of dry matter, crude protein, digestible energy and gross energy of diets (Table 3 ). The process of corn silage increased the digestibility coefficients of dry matter and crude protein and the digestible energy of diets $(\mathrm{P}<0.05)$. Similar results were obtained by Silva et al. (2005) for the coefficients of digestibility of dry matter and crude protein,

Table 3 - Digestibility of dry matter, crude protein and energy in diets containing flint corn or dent corn in the form of dry grain or moist grain silage

\begin{tabular}{lccc}
\hline Item & $\begin{array}{c}\text { Dry } \\
\text { grain }\end{array}$ & $\begin{array}{c}\text { Moist grain } \\
\text { silage }\end{array}$ & Mean \\
\hline Dry matter & & & \\
Flint corn & 85.15 & 86.98 & 86.07 \\
Dent corn & 86.43 & 87.05 & 86.74 \\
Mean & $85.79 \mathrm{~b}$ & $87.01 \mathrm{a}$ & \\
Crude protein (\%) ${ }^{1}$ & & & \\
Flint corn & 85.35 & 90.03 & 87.67 \\
Dent corn & 86.31 & 89.03 & 87.69 \\
Mean & $85.83 \mathrm{~b}$ & $89.53 \mathrm{a}$ & \\
Gross energy $(\%)^{2}$ & & & \\
Flint corn & & & \\
Dent corn & 86.77 & 86.27 & 86.52 \\
Mean & 85.49 & 86.88 & 86.41 \\
Digestible energy (kcal/kg) & & & \\
Flint corn & 86.13 & 86.57 & \\
Dent corn & & & \\
Mean & 3841 & 4022 & 3931 \\
\hline
\end{tabular}

${ }^{1}$ Means followed by different letters differ by $\mathrm{F}$ test $(\mathrm{P}<0.05)$.

2 Non-significant by $F$ test $(\mathrm{P}>0.05)$. but these authors observed lower values for digestible energy in animal experiments in growth-fed diets containing moist grain silage or dry ration.

The results obtained for digestible energy and the digestibility of dry matter and crude protein were higher than those observed by Oliveira et al. (2004). This increase may be related to the process of ensiling, which provides a favorable environment for the formation of organic acids produced during the fermentation process. These acids can cause ruptures in the structures covering the granules of starch, gelatinization of starch and partial opening of the pore structure of granules, favoring animal digestive processes (Lopes, 2000).

The type of corn did not influence the average daily gain, average daily feed intake or feed: gain ratio of the piglets $(\mathrm{P}>0.05)$ (Table 4). There were no effects of the type of corn or the form of storage on the average daily gain and average daily feed intake $(\mathrm{P}>0.05)$. Similar responses were found by Oliveira et al. (2004) when assessing levels of substitution of dry corn for moist grain silage for piglets in the initial phase.

Despite these results, feed conversion improved with the supply of dent corn compared to flint corn, regardless of whether the corn was provided in the dry grain form or moist grain silage $(\mathrm{P}<0.05)$. The interaction of corn type and storage form was not significant $(\mathrm{P}>0.05)$. This is probably due to the percentage of vitreous endosperm in dent corn (Cantarelli et al., 2007), which may have interfered directly in the digestive process of piglets.

Table 4 - Performance of piglets in the period from 1 to 28 days post-weaning fed diets containing flint corn or dent corn in the form of dry grain or moist grain silage

\begin{tabular}{|c|c|c|c|}
\hline \multirow[t]{2}{*}{ Item } & \multicolumn{2}{|c|}{ Storage form } & \multirow[t]{2}{*}{ Mean } \\
\hline & Dry & Moist grain silage & \\
\hline & \multicolumn{3}{|c|}{ Average daily feed intake (g of DM/day) ${ }^{1}$} \\
\hline Flint corn & 587 & 562 & 574 \\
\hline Dent corn & 580 & 556 & 568 \\
\hline Mean & 583 & 559 & \\
\hline \multirow[t]{2}{*}{ CV (\%) } & 14.4 & & \\
\hline & \multicolumn{3}{|c|}{ Average daily gain (g/day) ${ }^{1}$} \\
\hline Flint corn & 286 & 299 & 292 \\
\hline Dent corn & 310 & 311 & 310 \\
\hline Mean & 298 & 305 & \\
\hline \multirow[t]{2}{*}{ CV (\%) } & 12.5 & & \\
\hline & & Feed:gain ${ }^{2}$ & \\
\hline Flint corn & 2.05 & 1.87 & $1.96 \mathrm{~b}$ \\
\hline Dent corn & 1.87 & 1.78 & $1.82 \mathrm{a}$ \\
\hline Mean & $1.96 \mathrm{~b}$ & $1.82 \mathrm{a}$ & \\
\hline CV (\%) & 5.5 & & \\
\hline
\end{tabular}

${ }^{1}$ Non-significant by $\mathrm{F}$ test $(\mathrm{P}>0.05)$.

${ }^{2}$ Means followed by different capital letters in the column and small letters in the row differ by $\mathrm{F}$ test $(\mathrm{P}<0.05)$ 
In addition, the ensiling process of corn improved the feed conversion of the animals, regardless of the type of corn used. These results are similar to those reported by Tófoli et al. (2003) in an experiment using diets with dry corn and moist grain silage. According to these authors, a higher percentage of vitreous endosperm in grains undergoes hydrolysis under the anaerobic conditions in the silo; this may increase the availability of nutrients. Moreover, the formation of organic acids during the process of ensiling may also contribute to the improvement in the feed:gain ratio of piglets.

Several authors have reported positive effects from adding organic acids to the diets of piglets after weaning (Radcliffe et al., 1998; Omogbenigun et al., 2003). According to Holmes et al. (1974), increasing the total acidity of the diet and diets with the inclusion of wet corn promote better nutrient retention, better digestibility of protein in the stomach, and more uniform flow of digest into the small intestine. Moreover, the low-pH environment is responsible for a reduction in the number of pathogenic microorganisms, which may improve the performance of animals in the postweaning period.

\section{Conclusions}

The replacement of dry flint corn or dent corn with moist grain silage improves the digestibility of nutrients in the diet and provides a better feed: gain ratio for piglets from 7 to $15 \mathrm{~kg}$. Dent corn improves feed conversion relative to flint corn.

\section{Literature Cited}

ASSOTIATION OF OFFICIAL ANALYTICAL CHEMIST - AOAC. Official methods of analysis. 15.ed. Arlington, 1990. 1230p. ASCHE, G.L.; CRENSHAW, J.D.; LEWIS, A.J. et al. Effect of dry, high-moisture and reconstituted normal and high-lysine corn diets and particle size on energy and nitrogen metabolism in growing swine. Journal of Animal Science, v.63 p.131-138, 1986.

CANTARELLI, V.S.; FIALHO, E.T.; SOUSA, R.V. et al. Composição química, vitreosidade e digestibilidade de diferentes híbridos de milho para suínos. Ciência e Agrotecnologia, v.31, n.3, p.860-864, 2007.

COORS, J.G.; CARTER, P.R.; HUNTER, R.B. Corn Silage. In: HALLAVER, A.R. (Ed.) Speciality corns. Boca Raton: CRC Press, 1994. p.305-341.

CORREA, C.E.S.; PEREIRA, M.N.; OLIVEIRA, S.G. et al. Performance of Holstein cows fed sugarcane or corn silages of different grain textures. Scientia Agricola, v.60, n.4, p.621-629, 2003.

FIALHO, E.T.; ROSTAGNO, H.S.; FONSECA, J.B. et al. Efeito do peso vivo sobre o balanço energético e protéico de rações à base de milho e de sorgos com diferentes conteúdos de tanino para suínos. Revista Brasileira de Zootecnia, v.8, p.386-397, 1979.

FERREIRA, D.F. Análises estatísticas por meio do Sisvar para Windows versão 4.0. In: REUNIÃO ANUAL DA REGIÃO BRASILEIRA DA SOCIEDADE INTERNACIONAL DE BIOMETRIA, 45., 2000, São Carlos. Anais... São Carlos: UFSCar, 2000. p.255-258.

FORNASIERI FILHO, D. A cultura do milho. Jaboticabal: FUNEP, 1992. 273p.

HALE, O.M.; WILSON, D.M.; JAY, E. Acceptability and digestibility of swine diets containing corn stored under different conditions. Journal of Animal Science, v.47, p.46-50, 1978.

HOLMES, J.G.; BAYLEY, H.S.; HORNEY, F.D. et al. Digestion and absorption of dry and high-moisture maize diets in the small an large intestine of the pig. British Journal of Nutrition, v.30, p.401-410, 1973.

HOLMES, J.G.; BAYLEY, H.S.; HORNEY, F.D. et al. Digestion of dry and high-moisture maize diets in stomach of the pig. British Journal of Nutrition, v.32, p.639-646, 1974.

LIMA, G.J.M.M. Grãos de alto valor nutricional para a produção de aves e suínos: oportunidades e perspectivas. In: A PRODUÇÃO ANIMAL NA VISÃO DOS BRASILEIROS, 2001, Piracicaba. Anais... Piracicaba: Sociedade Brasileira de Zootecnia, 2001. p.178-194.

LIMA, J.A.F.; OLIVEIRA, A.I.; FIALHO, E.T. Suinocultura técnica. Lavras: UFLA/FAEPE, 1999. 203p.

LOPES, A.B.R.C.; BERTO, D.A.; COSTA, C. et al. Silagem de grãos úmidos de milho para suínos na fase inicial dos 8 aos $30 \mathrm{~kg}$ Boletim da Indústria Animal, v.58, n.2, p.181-190, 2001.

OLIVEIRA, R.P.; FURLAN, A.C.; MOREIRA, J. et al. Valor nutritivo e desempenho de leitões alimentados com rações contendo silagem de grãos úmidos de milho. Revista Brasileira de Zootecnia, v.33, p.146-156, 2004.

OMOGBENIGUN, F.O.; NYACHOTI, C.M.; SLOMINSKI B.A. The effect of supplementing microbial phytase and organic acids to a corn-soybean based diet fed to early-weaned pigs. Journal of Animal Science, v.81, p.1806-1813, 2003.

PEKAS, J.C. Versatile swine laboratory apparatus for physiologic and metabolic studies. Journal of Animal Science, v.27, p.1303-1306, 1968

RADCLIFFE, J.S.; ZHANG Z.; KORNEGAY, E.T. The effects of microbial phytase, citric acid, and their interaction in a cornsoybean meal-based diet for weanling pigs. Animal Science, v.76, p.1880-1886, 1998.

ROSTAGNO, H.S.; ALBINO, L.F.T.; DONZELE, J.L. et al. Tabelas brasileiras para aves e suínos: composição de alimentos e exigências nutricionais. Viçosa, MG: Editora UFV, 2005. 186p.

SALES, G.T.; FIALHO, E.T.; VOLPATO, C.E.S. Modificação nas gaiolas metabólicas para experimentos com suínos. In: CONGRESSO DE INICIAÇÃO CIENTÍFICA DA ESCOLA SUPERIOR DE AGRICULTURA DE LAVRAS, 26., 2003, Lavras. Anais... Lavras: Universidade Federal de Lavras, 2003. p. 249

SILVA, A.A.; MARQUES, B.M.F.P.; HAUSCHILD, L. et al. Digestibilidade e balanços metabólicos da silagem de grãos úmidos de milho para suínos. Ciência Rural, v.35, p.877-882, 2005.

TÓFOLI, C.A.; BERTO, D.A.; TSE, M.L. et al. Silagem de grãos úmidos de milho com diferentes teores de óleo para leitões em fase de creche. In: CONGRESSO BRASILEIRO DE VETERINÁRIOS ESPECIALISTAS EM SUÍNOS, 11., 2003, Goiânia. Anais... Goiânia: ABRAVES, 2003. (CD-ROM).

WATSON, S.A. Structure and composition. In: WATSON, S.A.; RAMSTAD, P.E. (Eds.) Corn: chemistry and technology. Saint Paul: American Association Cereal Chemistry, 1987. p.53-82. 